\title{
Purification and Characterization of Soymilk-clotting Enzymes from Bacillus sp. K-295G-7
}

\author{
Yang Won Park, Hideyuki Kobayashi, Isao KuSAKabe \\ and Kazuo MuraKami
}

Institute of Applied Biochemistry, University of Tsukuba, Ibaraki 305, Japan

Received March 3, 1987

\begin{abstract}
Enzymes I and II, which have a high soymilk-clotting activity, produced from K-295G-7 were purified by chromatographies on Sephadex G-100, CM-cellulose, hydroxylapatite, and 2nd Sephadex G-100.

The two purified enzymes were found to be homogeneous by polyacrylamide gel electrophoresis (PAGE) at pH 4.3. The molecular weights of enzymes I and II were 28,000 and 29,500 by SDS-PAGE, and their isoelectric points were 9.22 and 9.45, respectively. Enzymes I and II coagulated soymilk optimally at $65^{\circ} \mathrm{C}$ and were stable up to $45^{\circ} \mathrm{C}$. Both enzymes were most active at pH 5.8, for soymilk coagulation between pH 5.8 to 6.7 , and were stable with about $50 \sim 100 \%$ of the original activity from $\mathrm{pH} 5$ to 10 .

Each of the purified enzymes was a serine protease with an optimum $\mathrm{pH}$ of 9.0 for soy protein isolate (SPI) and casein digestions, because these enzymes were inhibited completely by diisopropylfluoro-phosphate (DFP).

The soymilk-clotting activity to proteolytic activity ratio of the enzyme II was 3 times higher than that of enzyme I. Enzymes I and II were more sensitive to the calcium ion concentration in soymilk than bromelain is.
\end{abstract}

Soybean contains useful human nutrients such as proteins, lipids and sugars. Soybean protein has a high nutritional value, thus the amount of soybean production in the world is about the same as that of meat production. ${ }^{1)}$ Soybean has been used as material for Japanese traditional foods such as tofu, yuba, miso, and soy sauce from ancient times. Soy protein is now much less used for its functional properties as a food material except as an additive for meat and marine products. ${ }^{2)}$ Although soymilk has been produced as a milk substitute, it has not become very popular in Japan. Fuke and Matsuoka ${ }^{3,4)}$ have investigated the production of a cheese-like food from soymilk by treatment with plant proteases. However, the cheese-like product of bromelain has the problem of being slightly bitter.

In a preceding paper, ${ }^{5)}$ we reported the screening of microorganisms producing soymilk-clotting enzymes, and the production and investigation of some properties of the enzyme. We also reported that the curd made with the enzyme from K-295G-7 had a smooth texture and a mild taste without any bitterness. Recently, we found that the isolated microorganism belonged to the gram-positive Bacillus species and it produced an alkaline protease.

We have undertaken the purification of the enzyme having high soymilk-clotting activity. The soymilk-clotting activity was separated into two fractions (enzymes $\mathbf{F}$ and II) during the purification steps. This paper deals with the purification and characterization of these two enzymes produced by Bacillus sp. K295G-7.

\section{MATERIALS AND METHODS}

Materials. SPI (soy protein isolate) powder was supplied from Nisshin Seifun Co., Ltd. and soymilk was from 
Kibun Food Chemifa. Co., Ltd. Bovine serum albumin, ovalbumin, elastin, diisopropyl-fluorophosphate (DFP), and soy bean trypsin inhibitor (STI) were from Sigma. Chymostatin, leupeptin, antipain, E-64, and pepstatin were from the Protein Research Foundation of Japan. Sephadex G-100 was obtained from Pharmacia, CM-52 was from Whatman, ampholite was from LKB, and hydroxylapatite was from Seikagaku Kogyo. All other chemicals were of reagent grade.

Culture Conditions. K-295G-7 was cultured in a 5-1 jar fermentor. The medium conposition and culture conditions were described previously. ${ }^{5}$ )

Enzyme assay. Soymilk-clotting activity. Soymilkclotting activity was measured by the method described previously. ${ }^{5)}$

Proteolytic activity. The assay mixture contained $1 \mathrm{ml}$ of $1.2 \%$ SPI (or hemoglobin or casein) in $0.1 \mathrm{M}$ Tris $-\mathrm{HCl}$ buffer ( $\mathrm{pH} \mathrm{9.0)} \mathrm{and} 200 \mu \mathrm{l}$ of the enzyme solution. The reaction was done at $50^{\circ} \mathrm{C}$ for $30 \mathrm{~min}$, and was stopped by the addition of $1 \mathrm{ml}$ of $0.55 \mathrm{~m}$ trichloroacetic acid, after which the absorbance of the filtrate was measured at $280 \mathrm{~nm}$. One unit of the activity was defined as the amount of enzyme which increases the absorbance 1.0 at $280 \mathrm{~nm}$ under the conditions described above.

Protein concentration. Protein was measured by the absorbance at $280 \mathrm{~nm}$, assuming that the absorbance at the concentration of $1 \mathrm{mg} / \mathrm{ml}$ is 1.0 .

Polyacrylamide gel electrophoresis. Analytical gel electrophoresis was done at $\mathrm{pH} 4.3 \mathrm{using} 7.5 \%$ gel by the method of Davis. ${ }^{6)}$ Protein was stained with Coomassie brilliant blue $\mathrm{R}$ and then destained with $7 \%$ acetic acid in $10 \%$ methanol.

Molecular weight measurement. The molecular weight of the enzymes was measured with Sephadex G-100 column $(3 \times 100 \mathrm{~cm})$ chromatography. Cytochrome $c(12,500)$, ovalbumin $(45,000)$, and bovine serum albumin $(68,000)$ were used as the molecular weight markers. SDSpolyacrylamide gel electrophoresis was done in $0.1 \%$ SDS- 0.1 м sodium phosphate buffer, $\mathrm{pH} 7.2$, at $8 \mathrm{~mA}$ per gel by the method of Weber and Osborn ${ }^{7)}$ and molecular weight markers (BDH Biochemicals, 14,300 71,500) were used.

Isoelectric focusing. Isoelectric focusing was done in a 110-ml column with ampholyte pHs $3 \sim 10$ and $6 \sim 9$ for $48 \mathrm{hr}$ at $720 \mathrm{~V}$ and $4^{\circ} \mathrm{C}$. After the run, $1.0-\mathrm{ml}$ fractions were collected and absorbance at $280 \mathrm{~nm}, \mathrm{pH}$, and soymilk-clotting activity were measured.

Amino acid analysis. Each of enzymes I and II was hydrolyzed in vacuo in $6 \mathrm{~N} \mathrm{HCl}$ at $110^{\circ} \mathrm{C}$ for $24 \mathrm{hr}$. The amino acid compositions of the enzymes were identified on a Durrum amino acid analyzer model D-500.

\section{RESULTS AND DISCUSSION}

\section{Purification of soymilk-clotting enzyme}

All operations were done at $4{ }^{\circ} \mathrm{C}$ throughout the purification steps.

Step I. Ammonium sulfate fractionation. Ammonium sulfate, $1.96 \mathrm{~kg}$, was added with continuous stirring to 3.51 (total activity; 760 units) of the culture broth of K-295G-7 to bring $80 \%$ saturation. After it was left overnight, the resultant precipitate was collected by filtration through a Buchner funnel with ToyoRoshi No. 2 filter paper, and the enzyme was dissolved in a small quantity of water. The filtrate was dialyzed against $0.04 \mathrm{M}$ potassium phosphate buffer, $\mathrm{pH}$ 6.1, concentrated to $40 \mathrm{ml}$ by ultrafiltration and used in further steps.

Step II. First gel filtration. Twenty $\mathrm{ml}$ of the concentrated sample was put on a column of Sephadex G-100 equilibrated with $0.04 \mathrm{M}$ potassium phosphate buffer $(\mathrm{pH}$ 6.1), and chromatographed. The milk-clotting enzyme fraction obtained was pooled and concentrated to $100 \mathrm{ml}$ by ultrafiltration.

\section{Step III. CM-cellulose chromatography.}

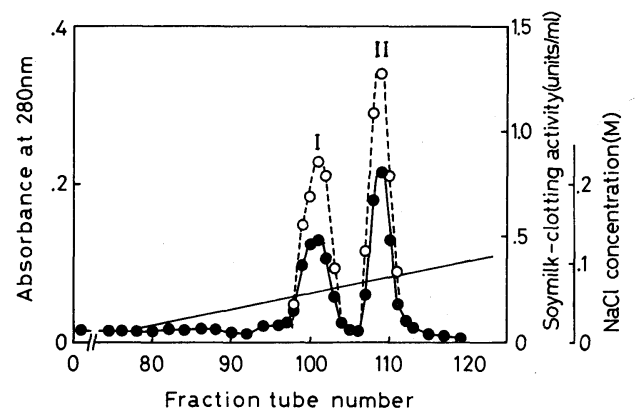

FIG. 1. Elution Profile of Soymilk-clotting Enzymes on CM-Cellulose Column.

The concentrate from step II, $100 \mathrm{ml}$ (total activity: 559 units), was put on a CM- 52 column $(2.5 \times 45 \mathrm{~cm})$ equilibrated with $0.04 \mathrm{M}$ potassium phosphate buffer ( $\mathrm{pH}$ 6.1). After the column was washed with the same buffer, the enzyme was then eluted with a linear gradient from 0 to $0.15 \mathrm{M} \mathrm{NaCl}$ in the same buffer $(300 \mathrm{ml}$ each) at the flow rate of $25 \mathrm{ml} / \mathrm{hr}$.

- - , absorbance at $280 \mathrm{~nm}$; --- $\bigcirc---$, soymilk-clotting activity; —-, $\mathrm{NaCl}$ concentration. 
The concentrate from step II was chromatographed on a CM-cellulose column. As shown in Fig. 1, the milk-clotting activity was separated into two fractions which were designated as enzyme I and enzyme II in the order of elution. Enzyme I and enzyme II were independently pooled, and dialyzed against $5 \mathrm{~mm}$ sodium phosphate buffer, $\mathrm{pH}$ 6.8 .

Step IV. Hydroxylapatite chromatography. Enzyme I and enzyme II were separately put on a column $(1.5 \times 30 \mathrm{~cm})$ of hydroxylapatite equilibrated with $5 \mathrm{~mm}$ sodium phosphate buffer ( $\mathrm{pH}$ 6.8). After the column was washed with the same buffer, the enzyme was eluted with a linear gradient from 0 to $0.2 \mathrm{M}$ sodium phosphate buffer $(300 \mathrm{ml}$ each) at the flow rate of $15 \mathrm{ml} / \mathrm{hr}$. The eluent was fractionated into $7.6 \mathrm{ml}$ portions. The fractions of enzyme I and II were pooled, dialyzed against $0.04 \mathrm{M}$ potassium phosphate buffer ( $\mathrm{pH}$ 6.1) and concentrated to $10 \mathrm{ml}$ by ultrafiltration.

Step $V$. Second gel filtration. Enzyme I and enzyme II from step IV were independently put on the column of Sephadex G-100 equilibrated with $0.04 \mathrm{M}$ potassium phosphate buffer ( $\mathrm{pH}$ 6.1), and chromatographed with the same buffer. These enzymes were eluted with single activity peaks which coincided well with the protein profile (data not shown).

The purification steps are summarized in Table I. Purified enzymes I and II were obtained with recoveries of $24.1 \%$ and $39.5 \%$, respectively.

\section{Homogeneity of enzymes I and II}

The homogeneity of purified enzymes I and II was examined by polyacrylamide gel electrophoresis at $\mathrm{pH}$ 4.3. As shown in Fig. 2, both enzymes were homogeneous, migrating as single bands on each gel.

\section{Molecular weight of enzymes I and II}

The molecular weight (MW) of enzymes I and II was 24,000 by Sephadex G-100 gel filtration. The MW of both enzymes was also measured by SDS-polyacrylamide gel electrophoresis. Enzymes I and II had MWs of 28,000 and 29,500, respectively. The molecular weights of both enzymes are similar to those of subtilisin BPN' and subtilisin Carlsberg. ${ }^{8)}$

\section{Isoelectric point}

Enzymes I and II had isoelectric points of pHs 9.22 and 9.45, respectively. These values closely resembled those of bacterial DFP-

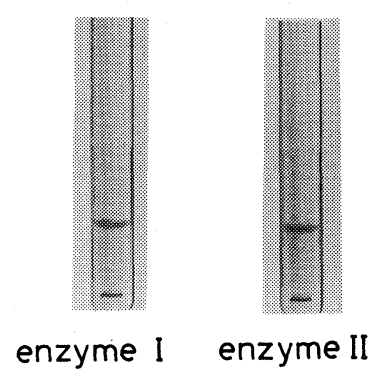

FIG. 2. Polyacrylamide Gel Electrophoresis of Enzymes I and II.

The electrophoresis was done at $3 \mathrm{~mA}$ per tube for $3 \mathrm{hr}$.

Table I. Purification of Soymilk-Clotting Enzymes

\begin{tabular}{lcccc}
\hline Steps & $\begin{array}{c}\text { Total activity } \\
\text { (units) }\end{array}$ & $\begin{array}{c}\text { Total protein } \\
(\mathrm{mg})\end{array}$ & $\begin{array}{c}\text { Specific activity } \\
\text { (units/mg protein) }\end{array}$ & $\begin{array}{c}\text { Recovery } \\
(\%)\end{array}$ \\
\hline Culture broth & 760 & - & - & 100 \\
$\left.\mathrm{NH}_{4}\right)_{2} \mathrm{SO}_{4}$ precipitation & 758 & 743 & 1.0 & 100 \\
Sephadex G-100 & 743.3 & 336 & 2.2 & 97.8 \\
CM-Cellulose I & 290.1 & 46.6 & 6.2 & 38.3 \\
II & 330.7 & 53.0 & 6.2 & 4.2 \\
Hydroxylapatite I & 234.6 & 32.4 & 10.6 & 30.9 \\
II & 308.3 & 29.2 & 8.5 & 40.6 \\
Sephadex G-100 I & 183.0 & 21.4 & 12.7 & 24.1 \\
II & 299.5 & 23.5 & 39.5 \\
\hline
\end{tabular}

-, not measured. 
Table II. Amino ACID Compositions OF ENZYMES I AND II

\begin{tabular}{|c|c|c|c|c|}
\hline \multirow{2}{*}{$\begin{array}{l}\text { Amino } \\
\text { acid }\end{array}$} & \multicolumn{4}{|c|}{ Residues per molecule } \\
\hline & $\begin{array}{c}\text { Enzyme } \\
\text { I }\end{array}$ & $\begin{array}{c}\text { Enzyme } \\
\text { II }\end{array}$ & $\begin{array}{c}\text { Subtilisin } \\
\text { BPN }^{\prime}\end{array}$ & $\begin{array}{c}\text { Subtilisin } \\
\text { Carlsberg }^{8)}\end{array}$ \\
\hline Asp & 25 & 29 & 28 & 28 \\
\hline Thr & 27 & 32 & 13 & 13 \\
\hline Ser & 32 & 25 & 37 & 32 \\
\hline Glu & 16 & 17 & 15 & 16 \\
\hline Pro & 9 & 11 & 14 & 9 \\
\hline Gly & 39 & 36 & 33 & 35 \\
\hline Ala & 25 & 24 & 37 & 41 \\
\hline Val & 18 & 18 & 30 & 31 \\
\hline Cys & 2 & 1 & 0 & 0 \\
\hline Met & 5 & 5 & 5 & 5 \\
\hline Ile & 19 & 21 & 13 & 10 \\
\hline Leu & 8 & 8 & 15 & 16 \\
\hline Tyr & 14 & 18 & 10 & 13 \\
\hline Phe & 8 & 9 & 3 & 4 \\
\hline Lys & 13 & 14 & 11 & 9 \\
\hline His & 4 & 2 & 6 & 5 \\
\hline Arg & 8 & 9 & 2 & 4 \\
\hline Total & 272 & 279 & 275 & 274 \\
\hline
\end{tabular}

The numbers of residues indicated are the averages of the analyses on the automatic amino acid analyzer.

sensitive alkaline proteases including subtilisin. $^{9)}$

\section{Amino acid composition}

The amino acids of enzymes I and II were analyzed to compare the amino acid composition with those of subtilisin $\mathrm{BPN}^{\prime}$ and subtilisin Carlsberg. ${ }^{8)}$ As shown in Table II, enzymes I and II had similar amino acid composition profiles. Both of these enzymes had a high content of aspartic acid, threonine, serine, glycine, and alanine, and a low content of cysteine. On the other hand, a large difference between both enzymes and subtilisin BPN $^{\prime}$ or subtilisin Carlsberg was recognized in the content of threonine, valine, isoleucine, and leucine. The occurrence of cysteine in both of enzymes I and II is particularly noteworthy. Thus, it is suggested from the above result that the species of Bacillus sp. K-295G-7 is different from Bacillus subtilis taxonomically.

\section{Enzymatic properties}

Thermal-activity profile. The soymilk-

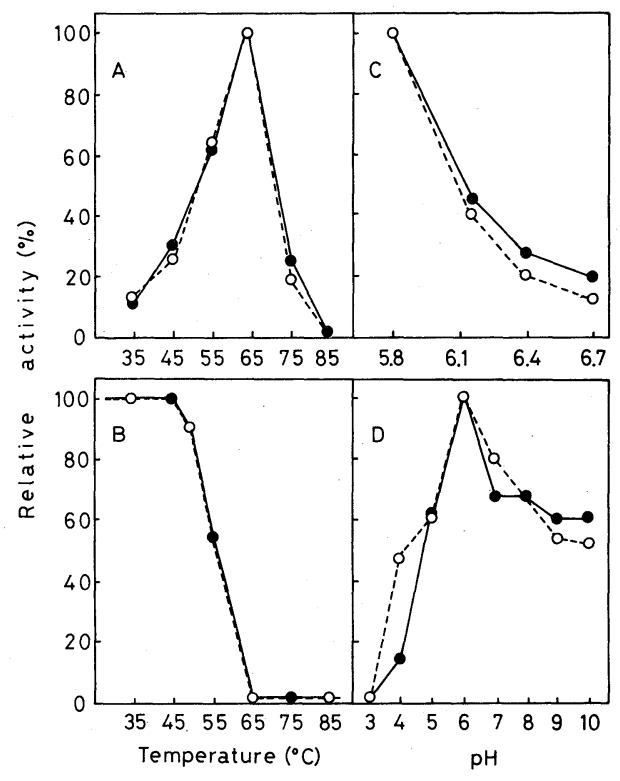

Fig. 3. Effects of temperature and $\mathrm{pH}$ on Activity and Stability of Soymilk-clotting Enzymes I and II.

A: Effects of temperature on the soymilk-clotting activity. Reaction mixtures containing $5 \mathrm{ml}$ of soymilk, adjusted to $\mathrm{pH} 6.1$, and $0.5 \mathrm{ml}$ of enzyme solution were incubated at various temperatures.

B: Effects of temperature on the stability of the enzymes. The enzyme solution ( $\mathrm{pH}$ 6.1) was left at various temperatures for $30 \mathrm{~min}$. Then the residual activity was measured. $\mathrm{C}$ : Effects of $\mathrm{pH}$ on the soymilk-clotting activity. Soymilkclotting activity was measured at different $\mathrm{pHs}$, ranging from $\mathrm{pH} 5.8$ to 7.0 , at $65^{\circ} \mathrm{C}$.

D: Effects of $\mathrm{pH}$ on the stability of the enzymes. One half $\mathrm{ml}$ of the enzyme solution and $0.5 \mathrm{ml}$ of McIlvaine buffer were mixed and stored at $37^{\circ} \mathrm{C}$ for $1 \mathrm{hr}$. After adjustment to $\mathrm{pH}$ 6.1, the residual activity was measured.

---, enzyme I; ---○---, enzyme II.

clotting activity of enzymes I and II was measured at various temperatures $\left(35 \sim 85^{\circ} \mathrm{C}\right)$ at $\mathrm{pH}$ 6.1. Figure $3 \mathrm{~A}$ shows the effects of temperature on soymilk-clotting activity. Both enzymes I and II had their optimum acitivity at $65^{\circ} \mathrm{C}$.

Thermal-stability profile. Enzymes I and II were separately maintained at various temperatures $\left(35 \sim 85^{\circ} \mathrm{C}\right)$ for $30 \mathrm{~min}$ at $\mathrm{pH} 6.1$, and then the remaining activities were measured. As shown in Fig. 3B, both enzymes were stable up to $45^{\circ} \mathrm{C}$.

pH-Activity profile. The soymilk-clotting activity of enzymes I and II was measured at 
different pHs ranging from 5.8 to 6.7 at $65^{\circ} \mathrm{C}$. The soymilk-clotting activity test could not be done below $\mathrm{pH} 5.8$, since the protein in soymilk coagulated without the addition of the enzyme solution below $\mathrm{pH}$ 5.8. Figure 3C shows the effects of $\mathrm{pH}$ on soymilk-clotting activity. Both enzyme activities decreased as the $\mathrm{pH}$ increased from 5.8 to 6.7 .

pH-Stability profile. Each of enzymes I and II was treated at different $\mathrm{pHs}(3 \sim 10)$ for $1 \mathrm{hr}$ at $35^{\circ} \mathrm{C}$; after that the remaining activities were measured. As shown in Fig. 3D, about $50 \sim 100 \%$ of the original activities of both enzymes remained after treatment in the range of $\mathrm{pH} 5 \sim 10$.

The milk-clotting enzyme was separated into two fractions, that is, enzymes I and II, and each enzyme coagulated the protein in soymilk. This fact indicates that the coagulation of the protein was due to a single enzyme

Table III. Relative Proteolytic Activity toward VARIOUS PROTEINS

The enzymatic reaction was done at $\mathrm{pH} 9.0$ and $50^{\circ} \mathrm{C}$ for $30 \mathrm{~min}$.

\begin{tabular}{lcc}
\hline \multirow{2}{*}{ Substrate } & \multicolumn{2}{c}{ Relative activity $(\%)$} \\
\cline { 2 - 3 } & Enzyme I & Enzyme II \\
\hline SPI & 100 & 100 \\
Casein & 78 & 41 \\
Hemoglobin & 37 & 33 \\
Ovalbumin & 6 & 25 \\
BSA & 25 & 66 \\
Elastin & 4 & 6 \\
\hline
\end{tabular}

TABle IV. Ratio BetWeEn Soymilk-Clotting ACtivity AND Proteolytic Activity

Soymilk-clotting activity was measured as described in Materials and Methods. Proteolytic activity was determined with SPI as the substrate at $\mathrm{pH} 6.1$ and at $50^{\circ} \mathrm{C}$ for $10 \mathrm{~min}$.

\begin{tabular}{lc}
\hline Enzyme & $\begin{array}{c}\text { Soymilk-clotting activity/ } \\
\text { Proteolytic activity }\end{array}$ \\
\hline Crude enzyme & 49.5 \\
Enzyme I & 61.9 \\
Enzyme II & 207.6 \\
Bromelain & 93.0 \\
\hline
\end{tabular}

action, not the combined action of two enzymes. On the other hand, enzymatic properties, namely thermal-activity and -stability profiles or $\mathrm{pH}$-activity and -stability profiles, were in excellent-agreement between enzymes I and II. This suggests that the two enzymes can coagulate the protein efficiently under the same optimum conditions, i.e. at $\mathrm{pH} 5.8$ and $65^{\circ} \mathrm{C}$.

\section{Proteolytic and soymilk-clotting activities}

The optimum $\mathrm{pH}$ for proteolysis of enzymes I and II was pH 9.0 on soy protein isolate (SPI), and 10.0 on hemoglobin (data not shown). This indicates that both of the enzymes are of alkaline proteases. On the other hand, the optimum temperature for proteolysis of the two enzymes was $50^{\circ} \mathrm{C}$ on hemoglobin (data not shown).

Table III shows the relative activity toward

Table V. Effects of Metal Ions on SoymilkClotting ACtivity and on Proteolytic ACTIVITY OF ENZYMES I AND II

\begin{tabular}{|c|c|c|c|c|}
\hline \multirow[t]{2}{*}{ Compound } & \multicolumn{2}{|c|}{$\begin{array}{c}\text { Relative } \\
\text { soymilk-clotting } \\
\text { activity }(\%)^{a}\end{array}$} & \multicolumn{2}{|c|}{$\begin{array}{c}\text { Relative } \\
\text { proteolytic } \\
\text { activity }(\%)^{b}\end{array}$} \\
\hline & Enzyme & zzyme II & Enzyme & zyme II \\
\hline None & 100 & 100 & 100 & 100 \\
\hline $\mathrm{KCl}$ & 92 & 97 & 105 & 104 \\
\hline $\mathrm{FeCl}_{2}$ & 128 & 249 & 96 & 100 \\
\hline $\mathrm{CaCl}_{2}$ & 142 & 204 & 90 & 99 \\
\hline $\mathrm{PbCl}_{2}$ & 100 & 130 & 90 & 75 \\
\hline $\mathrm{SnCl}_{2}$ & 148 & 243 & 71 & 82 \\
\hline $\mathrm{MnCl}_{2}$ & 238 & 230 & 97 & 94 \\
\hline $\mathrm{MgCl}_{2}$ & 209 & 212 & 87 & 94 \\
\hline $\mathrm{HgCl}_{2}$ & - & - & 60 & 84 \\
\hline $\mathrm{ZnCl}_{2}$ & - & - & 51 & 86 \\
\hline $\mathrm{BaCl}_{2}$ & - & - & 82 & 85 \\
\hline $\mathrm{CuCl}_{2}$ & - & - & 81 & 94 \\
\hline $\mathrm{CoCl}_{2}$ & - & - & 105 & 89 \\
\hline
\end{tabular}

a Reaction mixture contained $1 \mathrm{ml}$ of soymilk containing $1 \mathrm{~mm}$ of metal ions, adjusted to $\mathrm{pH} 6.1$, and $0.1 \mathrm{ml}$ of enzyme solution, and the enzyme reaction was done at $65^{\circ} \mathrm{C}$.

$b$ The assay mixture contained $1 \mathrm{ml}$ of $1.2 \%$ hemoglobin in $0.1 \mathrm{M}$ Tris- $\mathrm{HCl}$ buffer, $\mathrm{pH} 9.0,1 \mathrm{~mm}$ of metal ions, and $200 \mu \mathrm{l}$ of the enzyme solution. The enzyme reaction was done at $50^{\circ} \mathrm{C}$ for $10 \mathrm{~min}$. -, not measured. 
various proteins when enzymes I and II acted under the above optimum conditions. The highest rates of proteolysis, among the proteins examined, were obtained with SPI. Both of the enzymes also hydrolyzed casein, hemoglobin, etc. at different rates.

The ratio of soymilk-clotting activity to proteolytic activity

As shown in Table IV, each ratio of enzymes I and II was about 1.3 and 4 times higher than that of the crude enzyme, respectively. Bromelain was about 2 times higher than that

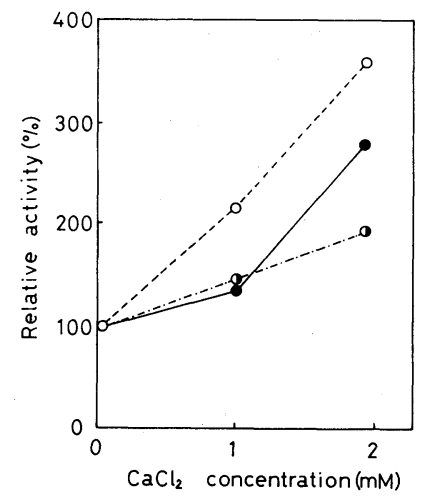

FIG. 4. Effects of Calcium Concentration on Soymilkclotting Activity.

Soymilk-clotting activity was measured at $65^{\circ} \mathrm{C}$ with the indicated concentration of calcium chloride in soymilk.

- - - enzyme I; --- ---- , enzyme II; -.-O-.--, bromelain.

Table VI. EFFects of Various Inhibitors ON SOYMILK-CLOTTING ENZYMES

\begin{tabular}{|c|c|c|c|}
\hline \multirow{2}{*}{ Reagent } & \multirow{2}{*}{$\begin{array}{l}\text { Concentration } \\
(\mathrm{mm})\end{array}$} & \multicolumn{2}{|c|}{$\begin{array}{c}\text { Remaining activity } \\
(\%)\end{array}$} \\
\hline & & Enzyme & Izyme II \\
\hline None & & 100 & 100 \\
\hline EDTA & 10 & 98 & 100 \\
\hline DFP & 2.5 & 0 & 0 \\
\hline Antipain & 0.1 & 98 & 100 \\
\hline Pepstatin & 0.1 & 100 & 100 \\
\hline Leupeptin & 0.1 & 95 & 100 \\
\hline Chymostatin & 0.1 & 86 & 68 \\
\hline Phosphoramidon & 0.1 & 92 & 100 \\
\hline E-64 & 0.1 & 86 & 90 \\
\hline Cysteine & 1 & 86 & 90 \\
\hline STI & 1 & 95 & 100 \\
\hline
\end{tabular}

of the crude enzyme. This result indicates that the enzyme II coagulates soymilk most effectively among these enzymes.

\section{Effects of metal ions on -soymilk-clotting activity}

Table V summarizes the effects of metal ions on the soymilk-clotting activity and on the proteolytic activity of enzymes I and II. With the addition of $1 \mathrm{~mm}$ metal ions such as $\mathrm{Fe}^{2+}$, $\mathrm{Ca}^{2+}, \mathrm{Sn}^{2+}, \mathrm{Mn}^{2+}$, and $\mathrm{Mg}^{2+}$, clotting activity of enzyme II was enhanced by two times while only $\mathrm{Mn}^{2+}$ and $\mathrm{Mg}^{2+}$ were effective for enzyme I. With metal ions such as $\mathrm{Hg}^{2+}$, $\mathrm{Zn}^{2+}, \mathrm{Ba}^{2+}, \mathrm{Cu}^{2+}$, and $\mathrm{Co}^{2+}$, the soymilk coagulated at $65^{\circ} \mathrm{C}$ without enzymatic action. The proteolytic activity was measured with hemoglobin as the substrate, because soybean protein isolate (SPI) was easily precipitated by the addition of $1 \mathrm{~mm}$ various metal ions at $50^{\circ} \mathrm{C}$. The proteolytic activity of enzymes I and II was affected by metal ions in various degrees. For instance, enzyme I was inhibited by $\mathrm{Hg}^{2+}$ and $\mathrm{Zn}^{2+}$ significantly, whereas enzyme II was not so much affected by the metal ions including $\mathrm{Hg}^{2+}$ and $\mathrm{Zn}^{2+}$. These results suggest that the effects of metal ions such as $\mathrm{Fe}^{2+}$, $\mathrm{Ca}^{2+}, \mathrm{Sn}^{2+}, \mathrm{Mn}^{2+}$ and $\mathrm{Mg}^{2+}$ is not on the enzymatic activity but on the soymilk coagulation process to a different degree.

Figure 4 shows the effects of calcium concentration on the soymilk-clotting activity of enzymes I and II, compared with that on bromelain. Both enzymes were more sensitive to calcium ion concentration for soymilk coagulation than bromelain. Raising the calcium concentration increased the soymilk coagulability to about $350 \%$ on enzyme II. When the calcium concentration exceeded $3 \mathrm{~mm}$, soymilk coagulation occurred without the addition of enzyme.

\section{Effects of enzyme inhibitors}

As shown in Table VI, both enzymes I and II were completely inhibited by DFP and partially by chymostatin. The inhibition by DFP suggests that both enzymes belong to the group of serine proteases. 
Acknowledgment. This work was supported in part by a grant from the Foundation for Promotion of Food Science and Technology.

\section{REFERENCES}

1) FAO Production Yearbook, Vol. 38, Food and Agriculture Organization of the United NationsRome, 1985, pp. $228 \sim 239$.

2) L. P. Voutsinas, E. Cheung and S. Nakai, J. Food Sci., 48, 26 (1983).

3) Y. Fuke and H. Matsuoka, J. Food Sci., 49, 312 (1984).

4) Y. Fuke, M. Sekiguchi and H. Matsuoka, J. Food
Sci., 50, 1283 (1985).

5) Y. W. Park, I. Kusakabe, H. Kobayashi and K. Murakami, Agric. Biol. Chem., 49, 3215 (1985).

6) D. T. Davis, Ann. New York Acad. Sci., 121, 404 (1964).

7) K. Weber and M. Osborn, J. Biol. Chem., 244, 4406 (1969).

8) F. S. Markland, Jr. and E. L. Smith, "The Enzymes," Vol. 3, ed. by P. D. Boyer, Academic Press, New York, 1971, pp. $561 \sim 608$.

9) H. Matsubara and J. Feder, "The Enzymes," Vol. 3, ed. by P. D. Boyer, Academic Press, New York, 1971, pp. $721 \sim 795$. 